OmniAkuatika, 12 (2): 1-10, 2016
ISSN: 1858-3873 print / 2476-9347 online
Research Article

\title{
Bathymetry and Hydrodynamics in Pare Bay Waters During Transitional Seasons (September- October)
}

\author{
Ulung Jantama Wisha ${ }^{1 *}$, Aida Heriati ${ }^{2)}$ \\ ${ }^{1)}$ Researcher in Research Institute for Coastal Resources and Vulnerability, Ministry of Marine Affairs and \\ Fisheries, JL. Raya Padang-Painan KM. 16, Teluk Bungus Padang 25245 Indonesia \\ ${ }^{2)}$ Researcher in Agency for Research and Development of Marine and Coastal Resources, Ministry of Marine \\ Affairs and Fisheries, Komplek Bina Samudera JL. Pasir Putih II Lantai 4, Ancol Timur, Jakarta Utara 14430 \\ Indonesia \\ *Coresponding author : ulungjantama@gmail.com
}

Received 5 June 2016; Accepted 20 October 2016; Available online 29 November 2016

\begin{abstract}
Sedimentation on Pare bay and Karajae estuary originated from the run off of Karajae River. High sedimentation process leads to the adverse effect of abiotic environmental changes. The aim of this research is to analyse bathymetry condition and hydrodynamic characteristics of the area in understanding sediment distribution on Pare Bay. Corrected bathymetric data by tide data is processed using Surfer software 9.0 versions to analyse Pare Bay contour in $2 \mathrm{D}$ and $3 \mathrm{D}$, the result show depth ranges from 0 to 20 meters. Flow model module by MIKE 21 software was used in hydrodynamic simulation (MRSE 11.44\%) and shows that current condition in Pare Bay was dominated by tidal (within its speed up to $0.43 \mathrm{~ms}-1$ ), surface currents speed is higher and more random than the speed in water column and near bottom. Due to its location, Pare Bay is directly influenced by Indonesian Through flow which has strong currents flow and cause mixing and turbulence along its way, this condition influences Pare Bay condition, especially in the process of sedimentation and turbulence.
\end{abstract}

Keywords: bathymetry, currents, hydrodynamics, sedimentation, pare bay

\section{Introduction}

Pare Bay is located in South Sulawesi coastal area, it has about 2778 Hectares water area, $34 \mathrm{~km}$ coastline, and water depth of about 0.75 meters below the water surface within shallow depth at the northern part and reaches 20 meters at middle area. There are several estuaries wherein directly adjacent with Karajae river and intertidal zone potential in sedimentation and shallowing process on coastal and estuary area (Qarni, 2008).

Sedimentation along Pare bay and its surrounding area originated from material run of from Karajae River. The main factor of causing the silting is a class $\mathrm{C}$ mining excavation in upstream and downstream area, therefore the sedimentation is influenced by domestic waste flowing through rivers with its sediment particles (Qarni, 2008).

The increase of sedimentation brings adverse effects to biotic environment changes, such as coral, seagrass and seaweed covered by sediment, so that sedimentation process affect turbidity in the bay, reduce the bay depth, and directly disrupt shipping traffic at the harbor (Napitupulu et al., 2015). Mechanism transport in the bay tends to be weak, the waves entering to the bay will deform and reducing the wave energy and causing low water mass transport (Metzger and Hurlburt, 1996). Tidal currents at estuary moving at low speed and sediments originated from both land and sea are not transported maximally therefore it causes silting in the bay (Wisha et al., 2015).

An understanding of water area condition is needed to reduce the negative impact occur in coastal and marine area development planning. Current is one of the oceanographic components, current measurement can be done as the initially step in monitoring water conditions, before we see the current pattern as a whole by doing survey field mathematical approach (Hoekstra et al., 2002). Ecological modeling is alternative way which is cheaper and easier to do in getting existing distribution and future predictions (Nugroho and Anugroho, 2007). The aim of this research is to analyze bathymetry condition and hydrodynamic characteristics of the area in understanding sediment distribution on Pare Bay. 


\section{Material and methods}

This research conducted in Pare bay, Pare-pare, South Sulawesi on $16^{\text {th }}$ September until $6^{\text {th }}$ October 2015 collecting both primary and secondary data, primary data consists of bathymetry, sea currents and tide, whereas secondary data including bathymetry map from DISHIDROS and RBI map.

Bathymetry data is recorded by Echo sounder Echotrak CVM Teledyne Odom Hydrographic Single beam to determine seabed morphology and using sounding method and also using RTK GPS Trimble for the accuracy of coordinate position. Echo sounder work with receiving wave sound energy pulse by the transducer towards the bottom of the waters, when that acoustic wave touches the bottom of the water will be reflected back and received by the transducer receiver. Depth data retrieval using a pattern aligned parallel, i.e. patterns sounding directions perpendicular and parallel to the inclined longitudinal line, in the other word, accordance with the parallel sounding pattern (Soeprapto, 2001).

The result of bathymetry measurement must be corrected for the position of the sea level (MSL, Zo and TWLt) at the time of measurement and corrected for distance drowning transducer in order to obtain the actual depth (Simanjuntak et al., 2012). Reduction or correction of the tidal formulated as follows:

$r t=T W L t-(M S L+Z o)$

Description:

Rt : Reduction or correction amount given to the result measurements depth at $t$ time

TWLt : Actual position of the sea level at $t$ time.

MSL : Average of sea level

Zo : : The depth in low tide under MSL

The equation above produces reduction magnitude for tide height, furthermore calculate the actual depth using following formula:

$$
D=d T-r t
$$

Description:
D : Actual depth
dT : Depth corrected by transducer
rt : tide reduction

Corrected bathymetry data then processed using Surfer 9 software for bathymetry contour analysis in $2 \mathrm{D}$ and $3 \mathrm{D}$ format and then overlaid with bathymetry data from DISHIDROS map digitation, both of them are used as input scatter data in flow model processes and also used tide forecasting by NAOTIDE software for time series in the models.

Sea current and tide data retrieval done at one observation station within coordinate $119,626334^{\circ} \mathrm{E}$ and $-3,985212^{\circ} \mathrm{S}$ that assumed the location was not disturbed by fisherman and vessel activities. The ADCP (Aquadopp Profiler - Nortek) (Table 1) instrument was used as a tool for recording the speed and direction of sea currents, temperature and tides. This tool is handy tool to obtain 15 Days data easily with blanking distance 0,5 meters (Wisha et al., 2015). ADCP is located in west part of Pare bay with 12 Meters depth (Figure $1)$.

Table 1. Acoustic Doppler Current Profiler Specification

\begin{tabular}{lc}
\hline Acoustic Frequency & $0,6 \mathrm{MHz}$ \\
\hline Max profile range & $30-40 \mathrm{~m}$ \\
\hline Cell size & $1-4 \mathrm{~m}$ \\
\hline Minimum Blanking & $0,50 \mathrm{~m}$ \\
\hline Max cell & 128 \\
\hline Velocity range & $\pm 10{\mathrm{~m} . \mathrm{s}^{-1}}^{1 \% \text { of measured }}$ \\
\hline Accuracy & value $\pm 0,5 \mathrm{~cm} . \mathrm{s}^{-}$ \\
& $1 \mathrm{~Hz}$ \\
\hline Max sampling range & \\
\hline
\end{tabular}

Data obtained in the form of velocity components in $\mathrm{U}$ and $\mathrm{V}$ direction. The value of the velocity components are given by the formula (Thurman and Alan, 2004):

$$
\begin{aligned}
& U=V_{\text {total }} \sin \left(\frac{\text { Dir } \pi}{180}\right) \\
& V=V_{\text {total }} \cos \left(\frac{\text { Dir } \pi}{180}\right)
\end{aligned}
$$

With $\pi$ is 3,14 and Dir is the current directions that measured. The calculate result for velocity and directions is used for flow models verification. Set up for hydrodynamic models is given in Table 2 . 
Table 2. MIKE21 Set-up for generate hydrodynamic models

\begin{tabular}{ll}
\hline Indicator & Implemented in simulation \\
\hline Simulation time & Number of Time step $=8759$ \\
& Time step interval $=3600 \mathrm{sec}$ \\
& Date of simulation $=16-09-1517.00$ until 8- \\
& $10-1509.00$ \\
\hline Mesh Boundary & Bathymetry $=$ DISHIDROS Bathymetry map \\
& digitation and field bathymetry data \\
& Coastline $=$ RBI map Digitation \\
\hline Flood and Dry & Drying depth $=0,005 \mathrm{~m}$ \\
& Flooding depth $=0,05 \mathrm{~m}$ \\
& Witting Depth $=0,1 \mathrm{~m}$ \\
\hline Boundary Condition & Tide forecasting data with coordinates : \\
& 1. Long : 119,$59758 ;$ Lat : $-4,0234$ \\
& 2. Long : 119,$60960 ;$ Lat : $-4,0252$ \\
& 3. Long : 119,$62066 ;$ Lat : $-4,0244$ \\
\hline
\end{tabular}

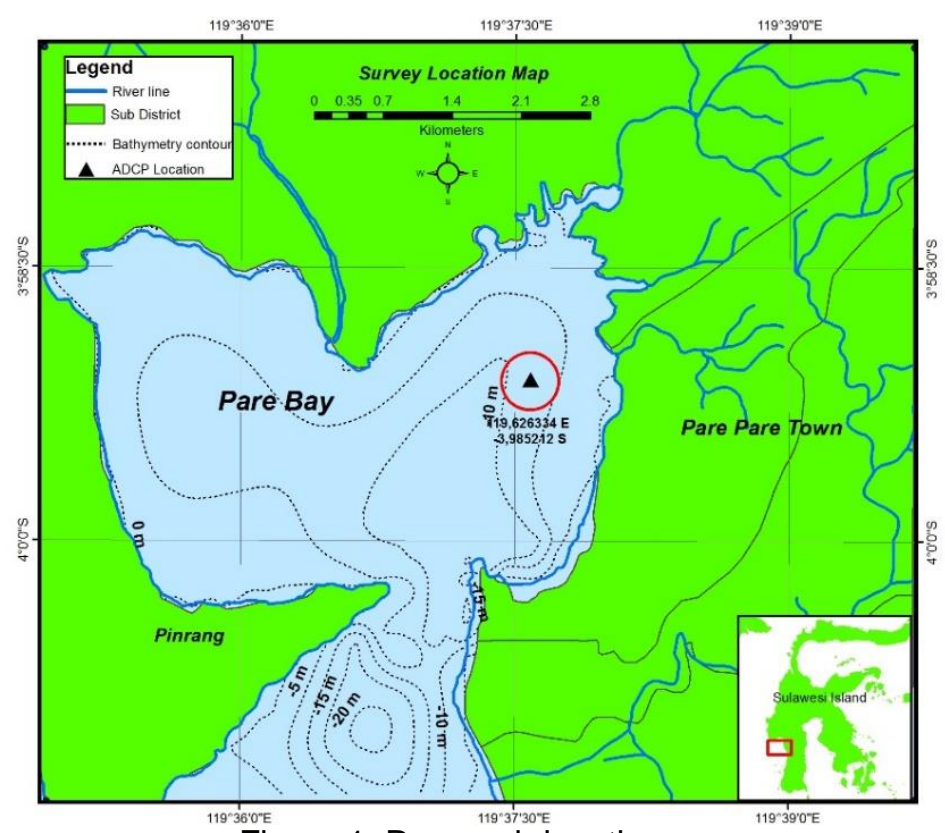

Figure 1. Research location map

\section{Result and discussion}

The result of water depth measurements (corrected depth and diminished transducer depth) is the actual depth measurement results (Simanjuntak et al., 2012), in which the depth outline of the bathymetric map is the average depth of mean sea level. To describe the contour lines based on MSL value (11.08 meters) from zero point ADCP. The results are used in tidal correction. The depth of Pare bay was calculated based on measurement at field survey using echo sounder and reduced by tidal correction. Tidal correction is elevation at field survey diminished by MSL value and the depth below surface (Zo) (Napitupulu et al., 2015) (Figure 2).

The fix sounding point isn't neat because of some obstacle when the sounding was in progress, such as limitation on boat stability, so that the pass rate is not in accordance with the lane plan. The result of bathymetry survey shows the depth of Pare Bay ranged from 0-20 meters (2D in Figure 3 and $3 D$ in Figure 4). Bathymetry data can be analyzed using bathymetry contour and isobaths. 


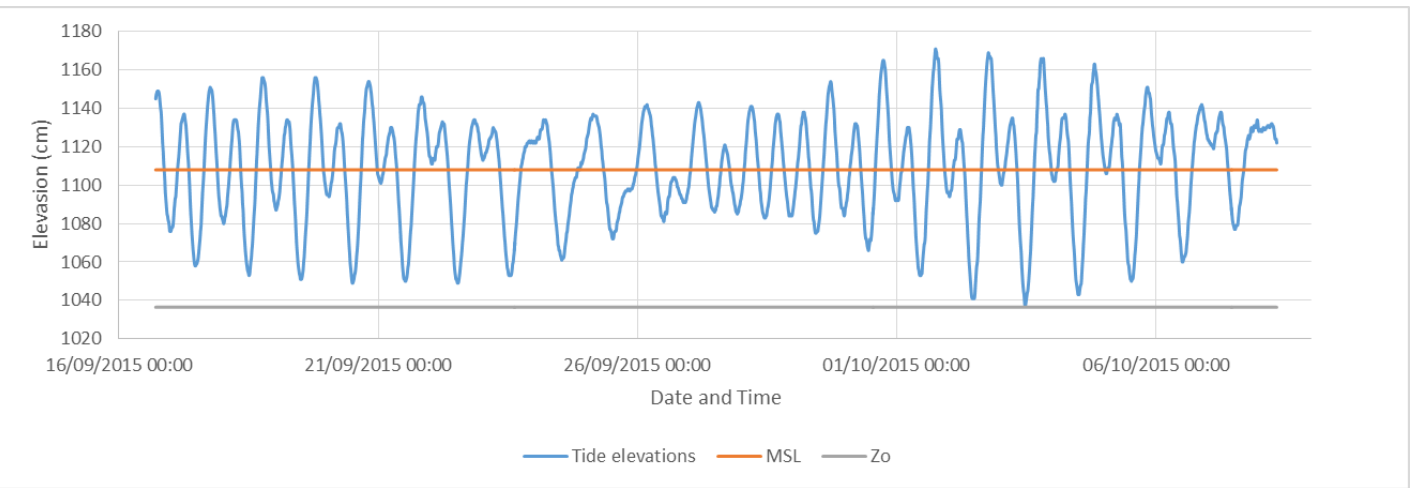

Figure 2. Tide conditions during research

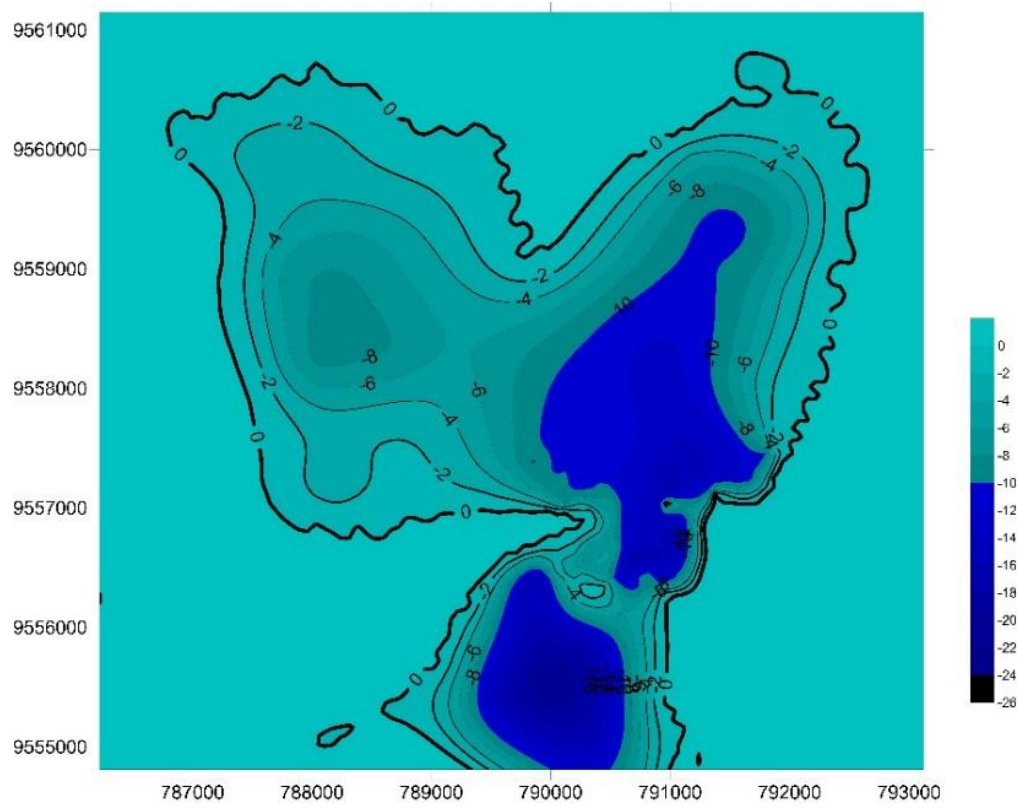

Figure 3. Surfer 9 analyze for bathymetry data in 2D

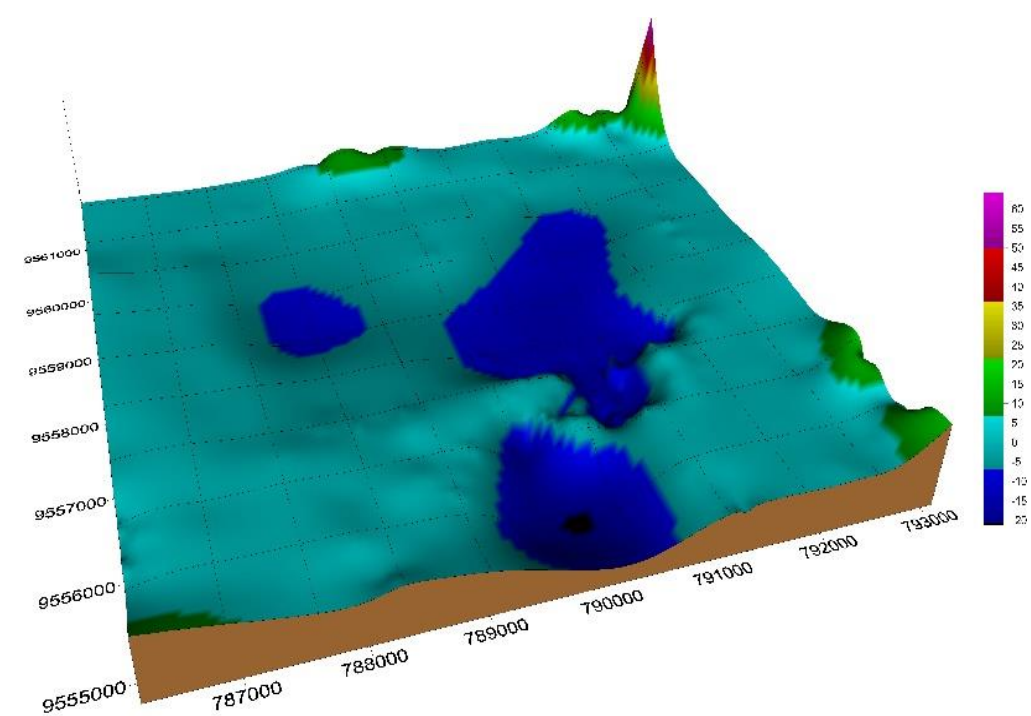

Figure 4. Surfer 9 analyze for bathymetry data in 3D 
On the East side near the mouth of the estuary at a depth of about -2 to - 10 meters, it appears that the contour of the closer and it indicates the area is steep, the location of the stretcher is a fishing port Cempae region, which is relatively more frequent dredging because the boat traffic lanes and as the location of the ship docked, according Napitupulu et al. (2015) that the bathymetry contour which narrows in a body of water indicates that the location is steeper than the contour of the region which is more tenuous.

At the mouth of the estuary there is a section which is very shallow, at the time of the survey, it appears that the shallow part of the ecosystems that hard massive coral, which directly sufficiently widened barrier in the path of the ship traffic, especially during conditions of low tide, plus the condition subsided, the speed of tidal currents and waves increased in the region, so it is quite dangerous for ships that pass at low tide, according Napitupulu et al. (2015) shipping lanes in the waters affected by the depth, where the reef, waves and tides, as well as the wind speed increases so that the waves were high.

Field data recording shows current movement in vertical flow in every cell represents the condition of low and high tide. Vertically, current moves by several factors, such as wind, tide, density and bed stresses (Hautala et al., 1986). Current movement isn't significant near the seabed due to bottom stress and density. Current movement is inhibited by bottom particles at deeper zone, so that current energy is being weaker, moreover higher density in the deeper zone leads to the slower current movement. In the other words, current movement is more stable at deeper zone (Hoitink and Hoekstra, 2003). Maximum speed in $U$ velocity is $0,16 \mathrm{~m} \cdot \mathrm{s}^{-1}$ and the minimum speed is $-0,17 \mathrm{~m} \cdot \mathrm{s}^{-1}$. Then the maximum speed in $\mathrm{V}$ velocity is $0,34 \mathrm{~m} . \mathrm{s}^{-1}$ and the minimum speed is $-0,12 \mathrm{~m} . \mathrm{s}^{-1}$ (Figure 5).

Current movement at the surface is influenced by several factors, such as wind speed and direction, and also tides. So that the flow becomes faster, in accordance with Wisha et al. (2015), current movement both vertically and horizontally are influenced by wind, tides, density and bottom stress. Pare bay dominated by tidal currents that flow vertically and horizontally movement also influence the mass transport of water in the bay pare (Wisha and Aida, 2016). According to Hoekstra et al. (2002) that the drift current in the surface is affected by the monsoon conditions and causing transport of particles suspended high in the territorial waters of bay.

The results from model simulation using MIKE 21 need to be verified by field data survey. Those can be seen on output data for surface elevation (Figure 6) and current speed and U-V direction (Figure 7). The figures show that both of surface elevation and current velocity have the same phase between model data and field data, but differ in amplitude. Surface elevation data is more irregular, because of the generation of wave and tide at the same time (Triadmodjo, 2014). Error value calculation from model data (RMSE) is 11,44 $\%$. Current speed model shows high current velocity inside Pare Bay ranges from 0 to 0,25 $\mathrm{m} . \mathrm{s}^{-1}$.

Hydrodynamic model performed at 4 condition, those are high spring tide condition (Figure 8), high neap tide condition (Figure 9), low spring tide condition (Figure 10), low neap tide condition (figure 10). Those conditions represent water flow dynamic around Pare Bay.

Simulation results in high tide condition showed that sea currents move towards the outer Pare Bay and away from the mainland. The same condition also occurred at high neap tide condition but differ in current speed. previous studies by Arifin et al. (2012) that the patterns of tidal current conditions at low to high spring tide shows the flow dominated by the movement toward the West away from coastal waters. 


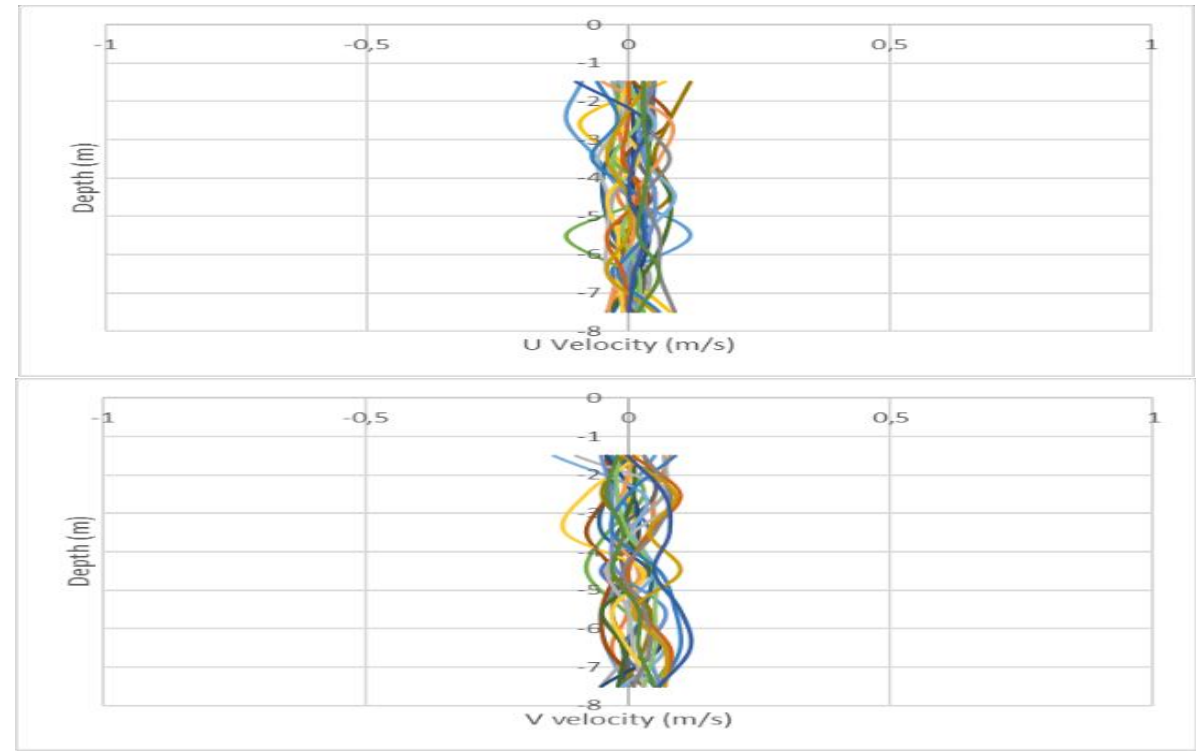

Figure 5. Sea Current components in $\mathrm{U}$ and $\mathrm{V}$ direction

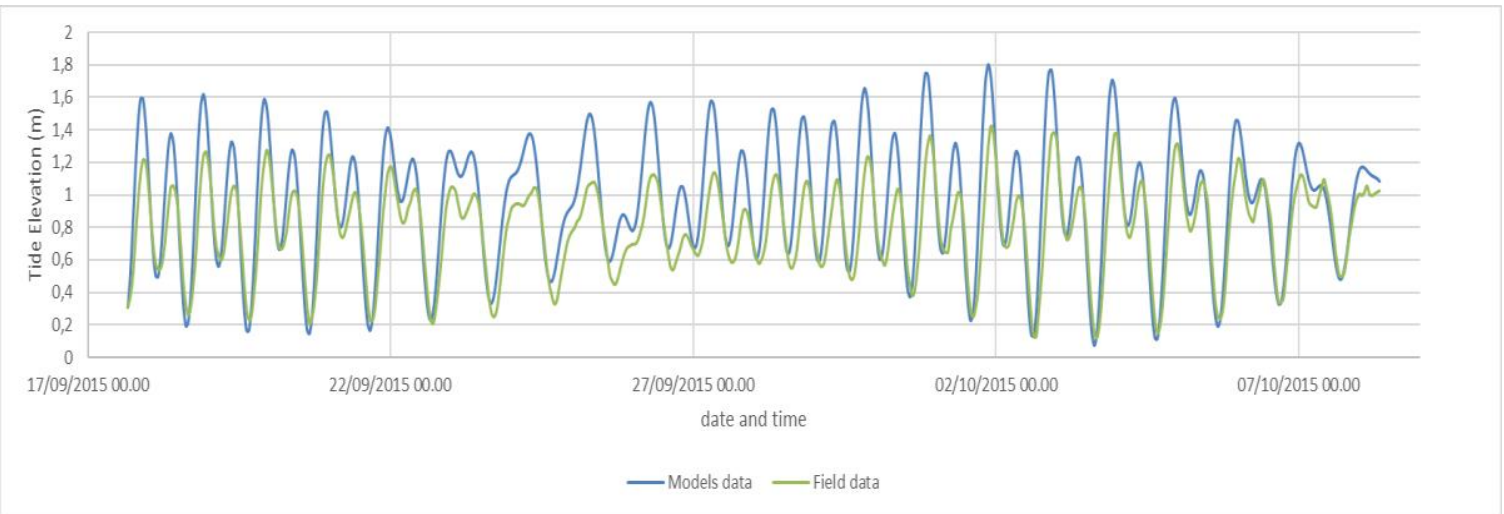

Figure 6. Surface elevation data verification

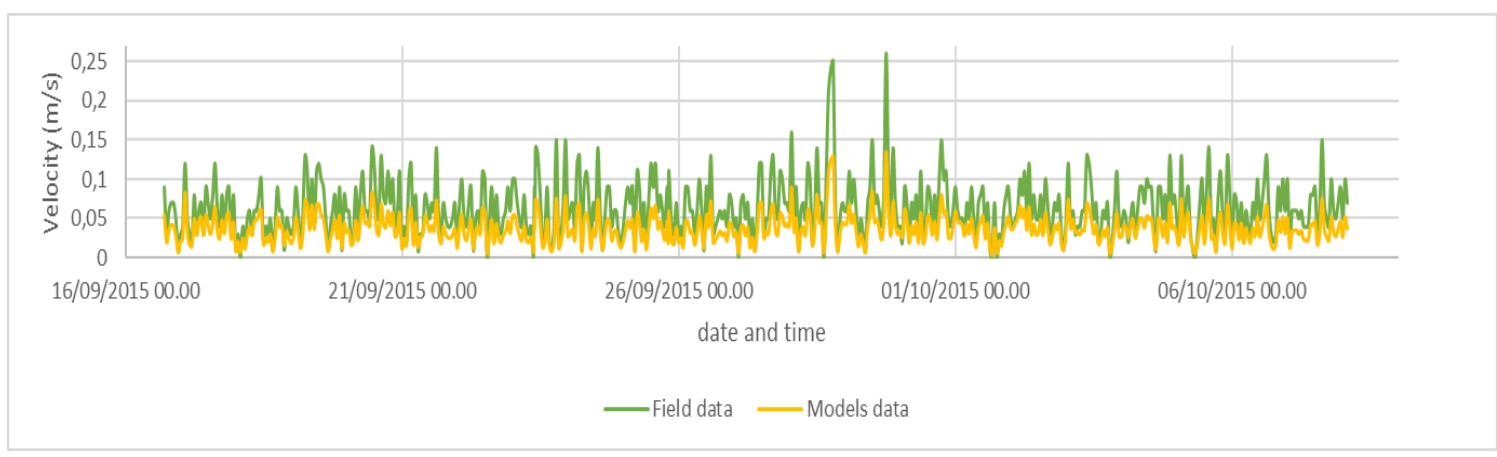

Figure 7. Current speed data verification

Current velocity in Pare Bay ranges from 0 $0,22 \mathrm{~m} . \mathrm{s}^{-1}$ (high spring tide condition) and from 0-0,36 m.s ${ }^{-1}$ (high neap tide condition), previous research by Rizal et al. (2009) that the pattern of current that passes through the Straits of Makassar headed south and turned east at the current speed of $0.4 \mathrm{~m} . \mathrm{s}^{-1}$. Maximum current speed occurred around the mouth of Pare Bay, 
whereas inside the bay, current speed at high spring conditions is stronger than at high neap tide and only some part in front of the bay has strong current due to shallow depth, narrow gap and dominated by hard massive coral ecosystem (Hoitink and Hoekstra, 2003). The existing ecosystem sometimes disrupt shipping channel and weak transport mechanism inside the bay may cause high sedimentation that leads to the shallowing bathymetry inside the bay, therefore dredging activities need to be done often (Hadi et al., 2006).

Pare Bay is located near Makasar Strait which is passed by Arlindo (Indonesian through flow), the flow causes the mixing and turbulence along path way (Gordon et al., 1999) that condition directly influence Pare Bay waters condition. Pare bay waters is semi covered area, within its weak transport mechanism that cause the shallowing bathymetry due to high sedimentation inside the bay and increasing turbulence at shallow area at high speed current. According Wisha and Heriati (2016) that is one of the pare bay directly adjacent to the Makasar Strait, thus directly Pare Bay conditions is strongly associated with the mechanism of circulation in the Strait of Makasar.

Hydrodynamics simulation result at spring tide condition (Figure 10) shows that current move toward mainland entering the bay, the same condition also occurred at low neap tide condition only with different current speed. Current speed ranges from $0-0,15 \mathrm{~m} . \mathrm{s}^{-1}$ (low spring tide condition) and ranges from $0-0,43$ m.s ${ }^{1}$ (low neap tide range). During low neap tide, current dynamic influence almost whole part inside the bay, and the current speed is stronger compare with at low spring condition. That phenomenon is caused by tensile strength between moon and sun during full moons which increase surface elevation (Shriver and Hurlburt, 1997), strengthen friction and expand fluid motion that leads to the weaker of current velocity (Gordon and Clean, 1999). During low tide conditions, tensile force between moon and sun are weaken each other, so the tidal elevation decreases, bottom friction increase and fluid motion be narrowed therefore the current speed becomes faster than full moon conditions, according to Arifin et al. (2012) water elevation reached its lowest water level at low tide neap conditions. Current condition (speed and direction) due to tidal condition changes influences distribution and sediment process inside the bay. According to Arifin et al. (2012), magnitude and direction of tidal residual current flow will determine spread and deposition process of various sediment and pollutant compositions in coastal area and elevation fluctuations (high to low water level and vive versa) will be followed by water mass movement (Hatayama et al., 1996).

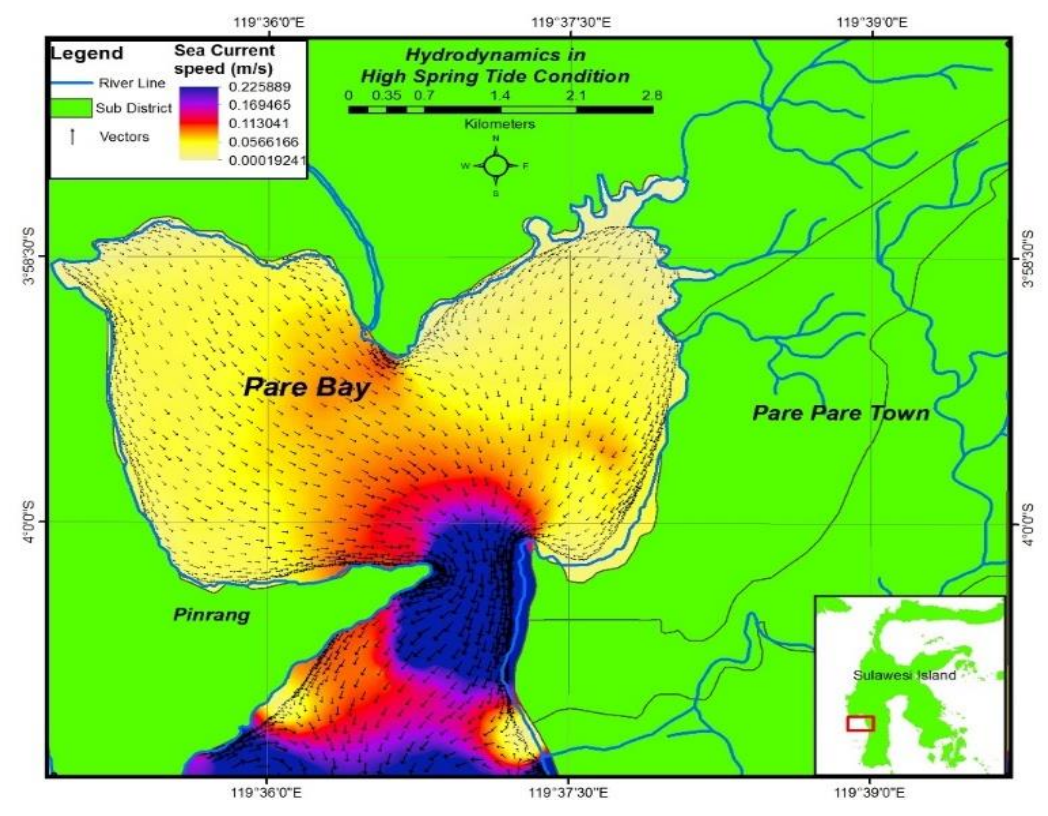

Figure 8. Current flow dynamics in High spring tide condition 

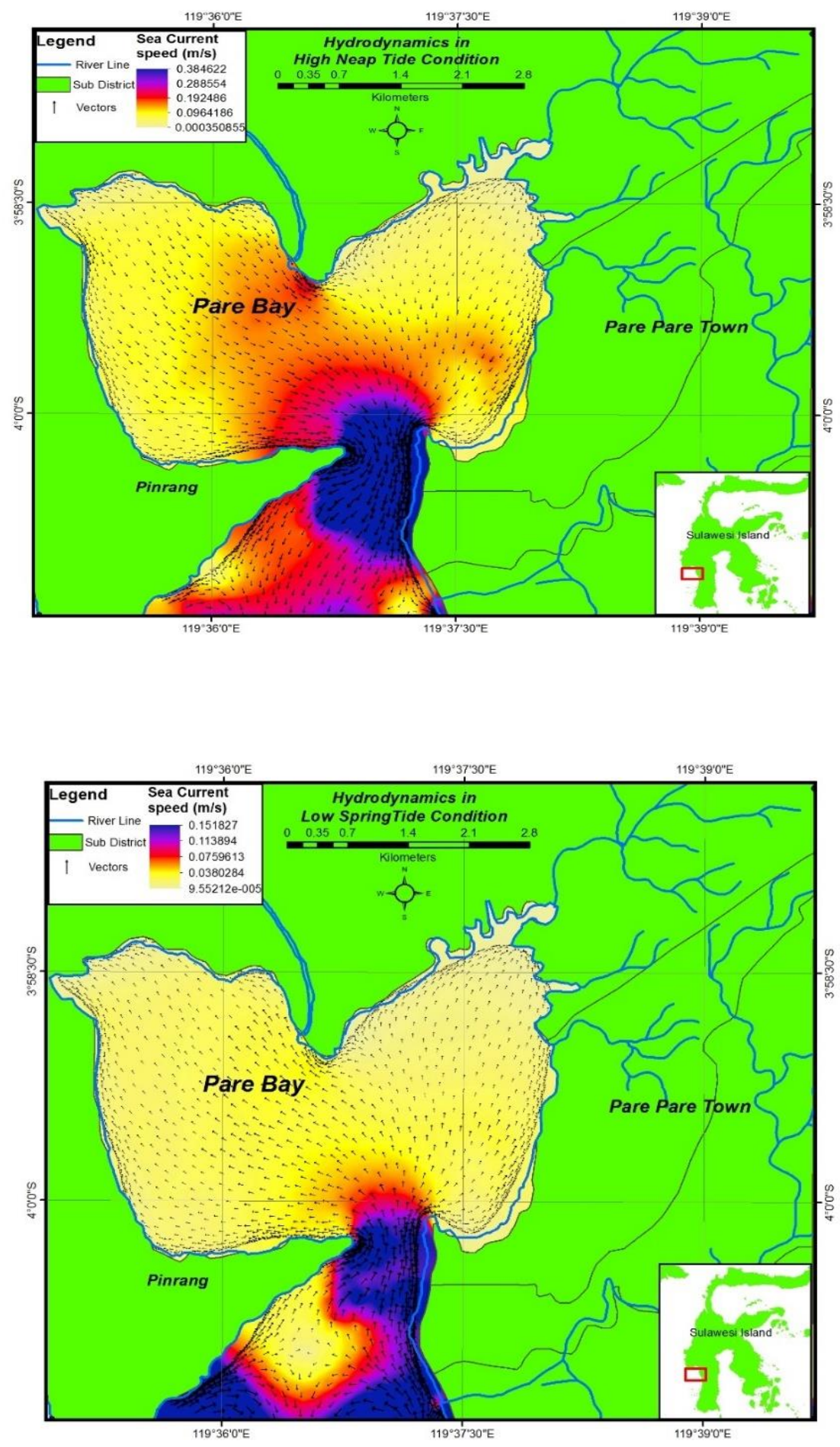

Figure 10. Current flow dynamics in low spring tide condition 


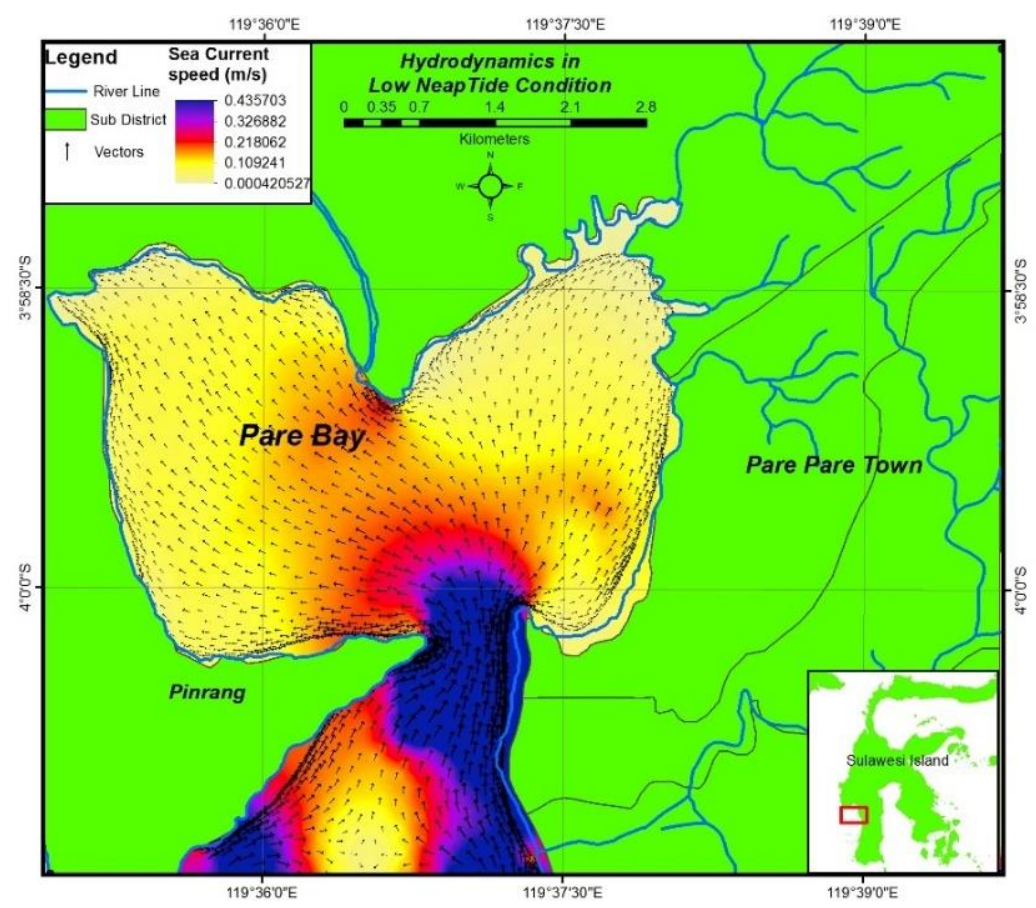

Figure 11. Current flow dynamics in low neap tide condition

\section{Conclusion}

The depth of Pare bay ranged from 0-20 meters, shallow area located at the northern part of the bay and bathymetry condition inside Pare bay is deeper than at mouth of Pare Bay. Hard coral ecosystems and narrow mouth bay size makes high current velocity around the area. Current velocity ranges from $0-0,36 \mathrm{~m} . \mathrm{s}^{-1}$ (high tide conditions) and ranges from $0-0,43$ m.s. (low tide conditions). Hydrodynamic processes over the area cause sedimentation and induce mixing and turbulence inside the bay, that increase turbidity due to the amount of sediment suspensions.

\section{Acknowledgement}

Authors acknowledge to the Research and development Centre of Marine and Coastal Resources (P3SDLP) for DIPA 2015 (APBNP Fishing Port Condition Monitoring), PPI Cempae, and for all those who helped in the implementation of this research.

\section{References}

Arifin, T., Y., Yulius, M. F. A., Ismail. 2012. Tidal Current Condition in Makassar waters, South Sulawesi. Jurnal Depik. 1(3):183-188.

Gordon, A., Susanto, D., Ffield, A. 1999. Troughflow within Makassar Strait. Journal of Geophysics Research 26(21): 3325-3328.

Gordon, A., Clean, J.M. 1999. Thermohaline Stratification of the Indonesian Seas: Model and Observation. Journal Physics Oceanography. 29. 198-216.

Hadi, S., Ningsih, N.S., Tarya, A. 2006. Study on Seasonal Variation of Cohesive Suspended Sediment Transport in Estuary of Mahakam Delta by Using $A$ Numerical Model. Jurnal Teknik Sipil. 13(1): 11-22.

Hatayama, T., Awaji, T., Akimoto, K. 1996. Tidal Currents in the Indonesian Seas and Their Effect on Tranpsort and Mixing. Journal of Geophysics Research.101(1).12353-12373. 
Hautala, S., Reid, J.L., Bray, N. 1986. The Distribution and Mixing of Pacific Water Masses in The Indonesian Seas. Journal of Geophysics Research.110(C5):1237512398.

Hoitink, A. J. F., Hoekstra, P. 2003. Hydrodynamic Control of the Supply of Reworked Terrigenous, Sediment to coral reefs in the Bay of Banten (NW Java, Indonesia). Journal Estuarine \& Coastal Shelf Science. 58(4): 743-755.

Hoekstra, P., Lindeboorn, H., Bak, R., Bergh, G.V.D., Tiwi, W., Douven, J., Heun, T., Hobma, T., Hoitink, W., Kiswara, E., Meesters, Y., Noor, N., Sukmantalya, S., Nuraini, T.V., Weering. 2002. An Integrated Coastal Zone Management Study. Staple (Ed.) Scientific Programme Indonesia-Netherlands Proceedings of a workshop held on February $12^{\text {th }} 2002$. Bandung. Indonesia. 59-70.

Metzger, E.J., Hurlburt, H.E. 1996. Coupled dynamics of the South China Sea, the Sulu Sea, And the Pacific Ocean. Journal of Geophysics Research. 101: 12331-12352.

Napitupulu, R.M.F, D.N., Sugianto., Hariyadi. 2015. Pemetaan Batimetri Sebagai Pertimbangan Penentuan Alur Pelayaran di Perairan Pulau Panjang, Jepara. Jurnal oseanografi. 4(1). 223-232.

Nugroho, D.S., Anugroho, A. 2007. Studi Pola Sirkulasi Arus Laut di Perairan Pantai Provinsi Sumatera Barat. Journal of Marine Science. 12(2). 79-92.

Qarny, U.A. 2008. Potensi Laut dan Pesisir Teluk Parepare. Jurnal Biotropika.1(5): 201-205.

Rizal, S., Setiawan, N.I.M., Muhammad, T., Iskandar, M.A., Wahid. 2009. Simulasi Pola Arus Baroklinik di Perairan
Indonesia Timur dengan Model Numerik Tiga-Dimensi. Jurnal Matematika and Sains. 14(4). 113-119.

Shriver, J. F., Hurlburt, H.E. 1997. The Contribution of the Global Thermohaline Circulation to the Pacific to Indian Ocean Troughflow Via Indonesia. Journal of Geophysics Research. 102(C3). 54915511.

Simanjuntak, B.L., Handoyo, G., Nugroho, D.S. 2012. Analisis Batimetri dan Komponen Pasang Surut untuk Penentuan Kedalaman Tambahan Kolam Dermaga di Perairan Tanjung Gundul Bengkayang - Kalimantan Barat. Jurnal Oseanografi. 1(1). 1-8.

Soeprapto. 2001. Muka Surutan Peta (Chart Datum dan Sounding Datum). Jurusan Teknik Geodesi. Fakultas Teknik. UGM. Yogyakarta. 202pp.

Sulaiman, A. 2000. Turbulensi Laut Banda (Studi Pendahuluan ARLINDO Microstructure). Dierktorat Teknologi Inventarisasi Sumberdaya Alam (TISDA). BPPT. 135pp

Triatmodjo, B. 2014. Perencanaan Bangunan Pantai. Beta Offset. Yogyakarta. 327pp.

Thurman, H.V., Alan, P.T. 2004. Introductory Oceanography. 10ed. Pearson Education, Inc. New Jersey. 188pp.

Wisha, U.J., Husrin, S., Prihantono, J. 2015. Hydrodynamics of Banten Bay During Transitional Seasons (AugustSeptember). Journal of Marine Science. 20 (2). 101-112.

Wisha, U.J., Heriati, A. 2016. Analysis of Tidal Range and Its Effect on Distribution of Total Suspended Solid (TSS) in the Pare Bay Waters. Journal of Marine Science and Technology.9 (1). 23-31. 